\title{
PERANAN SISTEM AKUNTANSI PENGGAJIAN DAN PENGUPAHAN DALAM MENDUKUNG PENGENDALIAN INTERN GAJI DAN UPAH PADA PT. ASDP INDONESIA FERRY (PERSERO) CABANG BAUBAU
}

\author{
Hasni \\ Program Studi Akuntansi, Fakultas Ekonomi \\ Universitas Muhammadiyah Buton, Baubau, Indonesia \\ e-mail :hasni76hasni@gmail.com
}

\begin{abstract}
ABSTRAK
Penelitian ini bertujuan untuk mengetahui sistem akuntansi penggajian dan pengupahan yang diterapkan oleh perusahaan dapat membantu manajemen dalam pengendalian intern gaji dan upah. Pengumpulan data dilakukan dengan menggunakan wawancara dan dokumentasi.

Hasil penelitian menunjukkan bahwa sistem akuntansi penggajian dan pengupahan pada PT. ASDP Indonesia Ferry (Persero) Cabang Baubau sudah cukup memadai guna dijadikan sebagai alat bantu pengendalian intern terhadap gaji dan upah. Struktur organisasi PT. ASDP Indonesia Ferry (Persero) Cabang Baubau sudah menggambarkan pemisahan fungsi yang jelas serta pembagian tugas dan tanggung jawabnya yang baik kepada tiap-tiap karyawan sehingga mendukung pengendalian intern perusahaan.
\end{abstract}

\section{Kata Kunci: Sistem Akuntansi, Penggajian dan Pengupahan, Pengendalian Intern}

\section{ABSTRACT}

This study aims to determine the payroll and wage accounting systems applied by companies can help management in internal control of salaries and wages. Data collection is using interviews and documentation.

The results of the study indicate that the payroll and wage accounting system at PT. ASDP Indonesia Ferry (Persero) Branch Baubau is sufficient enough to be used as an internal control tool for salaries and wages. The organizational structure of PT. ASDP Indonesia Ferry (Persero) Branch Baubau has described a clear separation of functions and the division of tasks and responsibilities that are good to each employee so as to support the company's internal control.

\section{Keywords: Payroll and Wage, Accounting System, Internal Control}

\section{PENDAHULUAN}

Perkembangan dan kemajuan perekonomian baik secara nasional maupun global yang terjadi dewasa ini cenderung mendorong berkembangnya perusahaan dan dapat memacu persaingan secara sehat serta memperkuat upaya mempertahankan usaha perusahaan dengan baik. Dengan berkembangnya perusahaan maka akan meningkatkan pula aktivitas yang harus dilakukan untuk mencapai tujuan perusahaan yaitu memperoleh laba. Untuk memperoleh laba yang optimal, perusahaan harus dapat menggunakan 
sumber daya yang penting dimiliki perusahaan yaitu diantaranya sumber daya manusia yang dimiliki perusahaan.

Pengelolaan sumber daya manusia yang tepat akan memberikan kontribusi yang optimal bagi perusahaan [1] jurnal uii. Salah satu unsur yang paling utama dalam mengelola sumber daya manusia adalah dengan menerapkan kebijakan kompensasi.

Kompensasi yang diterima karyawan dari perusahaan adalah gaji dan upah yang merupakan imbalan yang diberikan kepada karyawan sebagai balas jasa dari sumbangan yang telah diberikannya kepada perusahaan [2].Bagi perusahaan gaji dan upah merupakan biaya yang cukup besar jumlahnya dan salah satu unsur yang memiliki banyak resiko kemungkinan terjadinya manipulasi dan pemborosan, untuk itu manajemen perusahaan harus terus memberikan perhatian terhadap pengendalian internnya, dalam hal ini yaitu pengendalian intern gaji dan upah [3] Arens buku 2.

Pengendalian intern merupakan kebijakan dan prosedur yang melindungi kekayaan perusahaan dari penyalahgunaan, mengecek ketelitian dan keandalan akuntansi, dan memastikan bahwa peraturan yang berlaku dipatuhi sebagaimana mestinya [4].Untuk dapat menciptakan pengendalian intern tidak terlepas dari sistem akuntansi yang diterapkan oleh perusahaan.Sistem akuntansi merupakan serangkaian dari formulirformulir, catatan-catatan, laporan-laporan, serta alat-alat lainnya yang dikoordinasikan sehingga memberikan informasi yang diperlukan pimpinan perusahaan dalam pengambilan keputusan [5].

Terlepas dari itu semua harus disadari bahwa penyelewengan dan pemborosan bukan berarti sistem pengendalian intern itu lemah, tetapi merupakan pertanda bahwa terdapat kekurangan dalam pengendalian intern tersebut, yang harus diselidiki adalah apa penyebabnya [6].

Sistem akuntansi yang baik memperlihatkan prosedur urutankegiatan sehingga secara otomatis pengawasan telah berjalan. Bila ada kejanggalan dalam kegiatan operasi perusahaan akan mudah ditelusuri kembali sehingga dapat segera diketahui timbulnya masalah, dan manajemen perusahaan dapat segera mengambil keputusan serta langkahlangkah apa yang akan dilakukan guna mengatasi masalah tersebut. Dengan demikian terjadi hubungan yang erat antara sistem akuntansi dengan pengendalian intern dalam perusahaan termasuk pengendalian intern penggajian danpengupahan [7].

PT. ASDP Indonesia Ferry (Persero) Cabang Baubau, merupakan salah satu Badan Usaha Milik Negara (BUMN) yang bergerak dalam bidang usaha jasa penyeberangan kapal ferry. Perusahaan ini banyak mempekerjakan tenaga kerja dengan berbagai 
tingkatan. Perusahaan ini memberikan imbalan atas jasa karyawannya berupa gaji dan upah, dan telah menerapkan sistem akuntansi atas gaji dan upah untuk pengendalian atau pengawasan gaji dan upah. Jumlah karyawannya yang relatif banyak menyebabkan pengeluaran untuk gaji dan upah cukup besar dan penting, sehingga perlu mendapat perhatian yang memadai dari pihak manajemen perusahaan.

Dari uraian latar belakang diatas maka pertanyaan dari penelitian ini adalah bagaimana sistem akuntansi penggajian dan pengupahan yang diterapkan oleh PT. ASDP Indonesia Ferry (Persero) Cabang Baubau? Kemudian apakah sistem akuntansi penggajian dan pengupahan yang diterapkan oleh perusahaan dapat membantu manajemen dalam pengendalian intern gaji dan upah?.

\section{METODE PENELITIAN}

Berdasarkan jenis penelitian, data terbagi atas dua yaitu data kualitatif dan data kuantitatif.Data kuantitatif adalah data yang dapat diinput ke dalam skala pengukuran statistik.Fakta dan fenomena dalam data ini tidak dinyatakan dalam bahasa alami, melainkan dalam numerik.Sedangkan data kualitatif adalah data yang dapat mencakup hampir semua data non-numerik.Data ini dapat menggunakan kata-kata untuk menggambarkan fakta dan fenomena yang diamati [8].Jenis data yang digunakan dalam penelitian ini adalah data kualitatif.

Sumber data yang digunakan dalam penelitian ini adalah data primer dan data sekunder.Data primermerupakan data yang berasal dari sumber pertama yang dikumpulkan secara khusus dan berhubungan langsung dengan yang diteliti.Dalam penelitian ini data primer yang dikumpulkan berasal dari opini subjek yang diperoleh dari hasil wawancara [9].

Data sekundermerupakan sumber data penelitian yang diperoleh peneliti secara tidak langsung melalui media perantara (diperoleh dan dicatat oleh pihak lain) [8]. Dalam penelitian ini data sekunder yang digunakan adalah dokumen penggajian karyawan Tahun 2015 PT. ASDP Indonesia Ferry (Persero) Cabang Baubau, literatur-literatur, jurnal, serta artikel yang dibuat oleh pihak ketiga dan mempunyai relevansi dengan penelitian ini.

Populasi dalam penelitian ini adalah data sistem akuntansi penggajian dan pengupahan karyawan pada PT. ASDP Indonesia Ferry (Persero) Cabang Baubau.Sampel dalam penelitian ini adalah data sistem akuntansi penggajian dan pengupahan karyawan pada PT. ASDP Indonesia Ferry (Persero) Cabang Baubau periode tahun 2014 dan2015. 
Metode pengumpulan data yang digunakan dalam penelitian ini antara lain, metode studi pustaka dan studi lapangan. Studi kepustakaan dilakukan dengan cara membaca literatur-literatur tentang sistem akuntansi penggajian dan pengupahan. Untuk studi lapangan, pengamatan dan pengambilan data dilakukan dengan cara melakukan wawancara, observasi, dan dokumentasi [10].

Jenis penelitian yang digunakan dalam penelitian ini adalah penelitian deskriptif kualitatif. Tahap-tahap dalam menganalisis data yang berkaitan dengan penelitian ini adalah sebagai berikut:

1. Menggambarkan sistem akuntansi penggajian dan pengupahan yang diterapkan oleh PT. ASDP Indonesia Ferry (Persero) Cabang Baubau.

2. Menganalisis permasalahan yang timbul dalam penerapan sistem akuntansi penggajian dan pengupahan yaitu meliputi:

a. Struktur organisasi yang memisahkan tanggung jawab fungsional.

b. Sistem wewenang dan prosedur pencatatan pada sistem akuntansi penggajian dan pengupahan.

c. Penerapan pengendalian intern pada sistem akuntansi penggajian dan pengupahan.

\section{HASILDAN PEMBAHASAN}

\section{a. Hasil Penelitian}

\section{Kebijakan Sistem Akuntansi Penggajian dan Pengupahan}

Sistem akuntansi penggajian dan pengupahan tertuang dalam Keputusan Direksi PT. ASDP Indonesia Ferry (Persero) No.KD.52/PA.202/ASDP-2012 tanggal 05 Juni 2012 (Pasal 7), antara lain:

a. Periode perhitungan tunjangan kehadiran dimulai pada tanggal 20 pada bulan berjalan sampai dengan tanggal 20 bulan berikutnya.

b. Pembayaran gaji karyawan dilakukan setiap tanggal 25 setiap bulan, dan apabila tangal 25 jatuh pada hari libur (bukan hari kerja), maka pembayaran dimaksud akan dilakukan pada hari kerja sebelumnya yang terdekat dengan tanggal 25.

c. Pembayaran gaji karyawan dilaksanakan oleh unit kerja yang mengelola bidang SDM.

d. Pajak Penghasilan ( $\mathrm{PPh}$ 21) pembayaran gaji karyawan ditanggung oleh Perusahaan. 
e. Seluruh karyawan wajib diikutsertakan dalam Program BPJS Ketenagakerjaan, BPJS Kesehatan dan Progran Dana Pensiun.

\section{Sistem AkuntansiPenggajian dan Pengupahan}

Setelah melakukan serangkaian wawancara denganManager Keuangan, SDM \& Umum PT. ASDP Indonesia Ferry (Persero) Cabang Baubau, Bapak Rusmanto diperoleh informasi bahwa sistem akuntansi penggajian dan pengupahan pada PT. ASDP Indonesia Ferry (Persero) Cabang Baubau dirancang untuk menangani transaksi perhitungan gaji dan upah karyawan dan pembayarannya. Data-data dari karyawan disimpan secara akurat untuk merancang sistem penggajian dan pengupahan. Data-data karyawan dibuat dalam suatu data base secara terkomputerisasi.

Sistem akuntansi penggajian dan pengupahan yang diterapkan pada PT. ASDP Indonesia Ferry (Persero) Cabang Baubau menggunakan tiga unsur, yaitu dokumen yang digunakan, catatan akuntansi pendukung yang digunakan, dan jaringan prosedur yang membentuk sistem.

\section{Dokumen yang Digunakan dalam Sistem Akuntansi Penggajian dan Pengupahan}

Dokumen yang digunakan dalam sistem penggajian pada PT. ASDP Indonesia Ferry (Persero) Cabang Baubau adalah dokumen pendukung perubahan gaji, daftar hadir, daftar gaji karyawan, rekap daftar gaji, struk gaji dan bukti kas keluar. Sedangkan dokumen menurut teori [11] adalah dokumen pendukung perubahan gaji, kartu jam hadir, kartu jam kerja, daftar gaji karyawan, rekap daftar gaji, surat pernyataan gaji, amplop gaji, dan bukti kas keluar.

Hal ini dapat dilihat bahwa sistem akuntansi terhadap dokumen yang digunakan

PT. ASDP Indonesia Ferry (Persero) Cabang Baubau sudah cukup sesuai dengan teori, dokumen-dokumen di atas dijelaskan sebagai berikut:

1. Dokumen Pendukung Perubahan Gaji danUpah

Dokumen ini dikeluarkan oleh fungsi SDM berupa surat-surat keputusan yang bersangkutan dengan karyawan, seperti surat keputusan pengangkatan karyawan baru, surat keputusan kenaikan jabatan, perubahan besaran tunjangan kehadiran dan premi layar, pemberhentian, mutasi karyawan dan lain sebagainya.

2. Daftar Hadir/Absensi

Dokumen ini digunakan untuk mencatat waktu jam hadir setiap karyawan di perusahaan. Daftar hadir yang digunakan adalah dengan mesin finger 
print.Penggunaan finger print ini digunakan pada karyawan Kantor Cabang, mengingat luasnya cakupan wilayah kerja, misalnya untuk karyawan yang ada di lintasan, perusahaan memberikan kebijakanmenggunakan daftar absensi manual di bawah pengawasan pimpina unit kerja.

3. Daftar Gaji dan Daftar Upah

Setelah melakukan observasi terhadap dokumen pada PT. ASDP Indonesia Ferry (Persero) Cabang Baubau diperoleh hasil bahwa dokumen daftar gaji yang digunakan PT. ASDP Indonesia Ferry (Persero) Cabang Baubau terdiri atas 3, antara lain:

a) Daftar Gaji Karyawan

Dokumen ini berisi jumlah gaji kompetensi bruto setiap karyawan, ditambah tunjangan jabatan dan mobilitas, dikurangi potongan-potongan berupa potongan Astek, Dana Pensiun dan iuran organisasi karyawan.

b) Daftar Tunjangan Kehadiran,

Dokumen ini berisi jumlah kehadiran karyawan yang diperhitungkan berdasarkan daftar hadir karyawan.

c) Daftar Tunjangan Kapal/Premi Layar

Dokumen ini berisi jumlah tunjangan kapal yang diperhitungkan berdasarkan daftar hadir karyawan laut.

Daftar gaji dan tunjangan yang dibuat oleh bagian SDM disusun berdasarkan unit kerja, misalnya Daftar Gaji Karyawan Unit Kerja Kantor Cabang dan Daftar Gaji Karyawan Unit Kerja KMP. Nuku.

\section{Rekap Daftar Gaji}

Dokumen ini merupakan ringkasan gaji dan tunjangan bersih yang diterima karyawan. Daftar ini juga berisi data nomor rekening karyawan yang akan digunakan sebagai dasar transfer penggajian karyawan.

\section{Struk Gaji}

Dokumen ini memiliki bentuk yang sama dengan surat pernyataan gaji. Dokumen ini dibuat oleh fungsi SDM bersamaan dengan pembuatan daftar gaji dan upah atau dalam kegiatan yang terpisah dari pembuatan daftar gaji dan upah.Dokumen ini dibuat sebagai catatan bagi setiap karyawan mengenai rincian gaji dan upah yang diterima setiap karyawan beserta berbagai potongan yang menjadi beban karyawan.

6. Bukti KasKeluar 
Dokumen ini merupakan perintah pengeluaran uang yang dibuat oleh fungsi akuntansi kepada fungsi keuangan, berdasarkan informasi dalam daftar gaji dan upah yang diterima dari fungsi pembuat daftar gaji dan upah.Bukti Kas Keluar dibuat terpisah sesuai dengan mata anggaran yang digunakan perusahaan.

PT. ASDP Indonesia Ferry (Persero) Cabang Baubau tidak menggunakan amplop gaji karena pembayaran gaji dilakukan dengan cara mentransfer gaji ke rekening masing-masing karyawan.

\section{Catatan Akuntansi yang Digunakan dalam Sistem Akuntansi Penggajian dan Pengupahan}

Catatan akuntansi yang digunakan pada PT. ASDP Indonesia Ferry (Persero) Cabang Baubau telah mendukung dilihat dari adanya jurnal umum dan buku besar untuk merekam transaksi yang berkaitan dengan pemberian gaji dan upah karyawan.Pencatatan di dalam jurnal biasanya lebih lengkap dan lebih terinci, serta menurut urutan tanggal kejadian transaksi.Buku besar adalah kumpulan rekeningrekening yang digunakan untuk menyortasi dan meringkas informasi yang telah dicatat dalam jurnal.Jurnal untuk mencatat biaya gaji dibuat dalam dua tahap:

a. Tahap pertama, berdasarkan dokumen bukti kas keluar, dicatat oleh Kasir/Pemegang Kas ke dalam Buku Kas Operasional. Pencatatan biaya disesuaikan dengan Mata Anggaran yang digunakan oleh Perusahaan:

b. Tahap kedua, berdasarkan catatan Kasir/Pemegang Kas dalam Buku Kas Operasional serta dokumen bukti kas keluar yang telah dicap "lunas" fungsi keuangan, bagian Akuntansi mencatat pembayaran gaji ke dalam Jurnal secara komputerisasi, yang berisi tanggal transaksi, nomor bukti transaksi, kode cabang, segmen usaha, nomor akun, nama akun, debet dan kredit.

Dengan sistem penjurnalan secara komputerisasi, maka perusahan dengan mudah memposting transaksi ke dalam Buku Besar yang memuat informasi yang telah dicatat di dalam jurnal.

\section{Jaringan Prosedur yang Membentuk Sistem Akuntansi Penggajian dan Pengupahan}

Jaringan prosedur yang membentuk sistem akuntansi penggajian dan pengupahan pada PT. ASDP Indonesia Ferry (Persero) Cabang Baubau meliputi prosedur pencatatan 
waktu hadir, prosedur pembuatan daftar gaji dan upah, dan prosedur pembayaran gaji dan upah.

Sedangkan prosedur dalam sistem penggajian menurut teori adalah prosedur pencatatan waktu hadir, prosedur pembuatan daftar gaji, prosedur distribusi biaya gaji, dan prosedur pembayaran gaji [11].

Penjelasan setiap prosedur penggajian dan pengupahan karyawan PT. ASDP Indonesia Ferry (Persero) Cabang Baubau adalah sebagai berikut:

a. Prosedur Pencatatan Waktu Hadir

Pencatatan waktu hadir diselenggarakan oleh fungsi Sumber Daya Manusia dengan menggunakan daftar hadir manual maupun dengan mesin pencatat waktu. Dalam hal ini bagi karyawan di lintasan dan kapal sesuai kebijakan perusahaan dapat memakai daftar hadir manual, dimana karyawan harus menandatangani setiap kehadiran di bawah pengawasan pimpinan unit kerja. Bagi karyawan Kantor Cabang diisi secara otomatis dengan mesin finger print pada saat jam datang dan pulang kantor.

b. Prosedur Pembuatan Daftar Gaji dan Upah

Daftar gaji dan upah pada perusahaan dibuat oleh bagian Sumber Daya Manusia. Data yang dipakai bagian Sumber Daya Manusia adalah surat- surat keputusan mengenai pengangkatan karyawan baru, kenaikan jabatan, pemberhentian karyawan, mutasi karyawan, daftar gaji dan tunjangan bulan sebelumnya, dan rekap finger print/daftar absensi. Semua data dimasukkan ke dalam komputer yang mempunyai data base setiap karyawan. Lalu akan diproses dan menghasilkan daftar gaji dan upah. Dari keterangan tersebut dapat diketahui bahwa prosedur pembuatan daftar gaji dan upah telah dilaksanakan dengan baik.

c. Prosedur Pembayaran Gaji dan Upah

Prosedur ini melibatkan fungsi akuntansi dan fungsi keuangan. Sebelum melakukan prosedur pembayaran gaji dan upah, dilakukan pengecekan kesesuaian penjumlahan yang terdapat dalam daftar gaji dan upah oleh bagian keuangan, hal ini dapat mengurangi terjadinya salah saji yang dilakukan bagian penggajian dan agar dokumen yang dihasikan dapat diandalkan. Kemudian dibuatkan Bukti Kas Keluar.

Selanjutnya daftar gaji dan rekap daftar gaji diotorisasi oleh Manager Keuangan, SDM \& Umum, lalu dibawa oleh Kasir/Pemegang Kas ke bank untuk ditransfer ke rekening masing-masing karyawan.

Struk gaji diberikan kepada karyawan harus disetujui oleh Manager Keuangan, SDM \& Umum, lalu diberikan kepada pimpinan unit kerja masing-masing 
bagian.Kemudian pimpinan unit kerja akan membagikan struk gaji kepada setiap karyawan. Setiap karyawan harus menandatangani daftar gaji sebagai bukti penerimaan gaji. Pencatatan setiap transaksi dibuat ke dalam buku jurnal lalu kemudian diposting ke buku besar yang mana dasar pencatatannya adalah daftar gaji dan upah yang telah ditandatangani karyawan.

\section{b. Pembahasan}

\section{Sistem Pengendalian Intern atas Sistem Akuntansi Penggajian dan pengupahan}

Dari hasil wawancara peneliti dengan narasumber PT. ASDP Indonesia Ferry (Persero) Cabang Baubau tentang sistem pengendalian intern atas sistem penggajian pada PT. ASDP Indonesia Ferry (Persero) Cabang Baubau, maka diperoleh hasil sebagai berikut:

\section{Organisasi}

Dalam struktur organisasi PT. ASDP Indonesia Ferry (Persero) Cabang Baubau terlihat bahwa adanya pembagian yang jelas antar tiap bagian.Hal ini akan menyebabkan disiplin yang tinggi karena harus melaporkan hasil tugasnya tepat waktu kepada atasannya. Dengan demikian maka pengendalian terhadap karyawan mudah dilakukan.Pelaksanaan tanggung jawab setiap bagian secara umum telah berjalan dengan baik.Dimana fungsi pencatatan waktu hadir dan pembuatan daftar gaji dan upah dilakukan oleh bagian sumber daya manusia.Bagian keuangan terpisah dari fungsi pembuat daftar gaji danupah.Pemeriksa kesesuaian daftar gaji dan upah dengan bukti pengeluaran kas dilakukan oleh bagian keuangan.Pembayaran gaji dan upah dilakukan oleh Pemegang Kas (Kasir) setelah adanya persetujuan dari Manager Keuangan, SDM dan Umum.

\section{Sistem Operasi dan Prosedur Pencatatan}

Dari segi pemisahan tugas, maka setiap kegiatan dalam persiapan, perhitungan, serta pembayaran gaji dan upah harus mendapat persetujuan dari yang berwenang, yang berguna untuk menghindari adanya transaksi yang menyimpang dari semestinya.Dalam pembayaran gaji dan upah harus diotorisasi oleh fungsi keuangan dan mendapat persetujuan dari fungsi akuntansi kemudian dibayarkan kepada karyawan yang bersangkutan. Setiap potongan atas gaji dan upah karyawan selain dari pajak penghasilan karyawan didasarkan atas surat potongan gaji dan upah yang diotorisasi oleh bagian sumber daya manusia. 
Setiap karyawan yang namanya tercantum dalam daftar gaji dan upah harus memiliki surat pengangkatan karyawan yang ditandatangani oleh Direktur Utama. Bukti kas keluar untuk pembayaran gaji dan upah diotorisasi oleh fungsi akuntansi.Daftar hadir diotorisasi oleh bagian sumber daya manusia sebagai fungsi pencatat waktu.Daftar gaji dan upah diotorisasi oleh fungsi sumber daya manusia.Perubahan yang terjadi dalam catatan penghasilan karyawan direkonsiliasi dengan daftar gaji dan upah karyawan.

\section{Praktik yang Sehat}

Perusahaan telah menjalankan praktik-praktik yang sehat.Pembagian tanggung jawab fungsional dan pembagian wewenang dan prosedur pencatatan yang telah ditetapkan untuk menjamin praktek yang sehat dalam pelaksanaannya. Setiap transaksi tidak boleh dilaksanakan dari awal sampai akhir oleh satu orang atau satu unit organisasi, tanpa ada campur tangan dari orang atau unit organisasi lain.

Bagian sumber daya manusia sebagai fungsi pembuat daftar gaji dan upah, menyimpan catatan penghasilan karyawan.Perhitungan pajak penghasilan karyawan direkonsiliasi dengan catatan penghasilan karyawan.Bagian akuntansi memverifikasi kebenaran dan ketelitian pehitungan pembuatan daftar gaji dan upah sebelum dilakukan pembayaran. Pembayaran gaji dilakukan dengan cara mentransfer ke rekening masing-masing karyawan.

\section{KESIMPULAN}

Dari hasil analisis data, kesimpulan yang dapat ditarik dari penelitian ini ialah Prosedur dalam sistem penggajian pada PT. ASDP Indonesia Ferry (Persero) Cabang Baubau sudah cukup baik karena dalam proses penggajian, perusahaan melibatkan berbagai fungsi yang terkait secara terpisah dan sebelum membayar gaji karyawan, dokumendokumen serta catatan-catatan akuntansi yang digunakan harus diverifikasi dan mendapat otorisasi dari bagian yang berwenang.

\section{SARAN}

Saran yang dapat diberikan guna meningkatkan sistem penggajian dan pengupahan sebagai alat bantu pengendalian intern terhadap gaji dan upah adalah sebagai berikut: (1) penggunakan finger print untuk pengisian absensi karyawan agar diterapkan untuk semua karyawan baik Kantor Cabang, karyawan operasional di lintasan dan awak kapal; (2) perusahaan perlu mempertahankan sistem yang ada dan bila perlu lebih meningkatkan lagi pengendalian terhadap gaji danupah. 


\section{DAFTAR PUSTAKA}

[1] Nuryanta, N. 2008. Pengelolaan Sumber Daya Manusia (Tinjauan Aspek Rekrutmen dan Seleksi). Jurnal El-Tarbawi, Volume 1 Nomor 1.

[2] Hasibuan, Malayu. 2000. Manajemen Sumber Daya Manusia Edisi Revisi. Jakarta: PT. Bumi Aksara.

[3] Boynton C. William, Raymond N. Johnson, Walter G. Kell. 2003. Modern Auditing Edisi Ketujuh Jilid Satu. Alih Bahasa oleh Paul A. Radjoe, Gina Gania, Ichsan Setyo Budi. Jakarta: Penerbit Erlangga.

[4] Mulyadi. 2014. Sistem AkuntansiEdisi Ketiga. Jakarta: Salemba Empat.

[5] Baridwan, Zaki. 2009. Sistem Akuntansi: Penyusunan Prosedur dan Metode. Yogyakarta: BPFE

[6] Hartadi, Bambang. 2008. Sistem Pengendalian Intern dalam Hubungannya dengan Manajemen dan Audit Edisi 1. Yogyakarta: BPFE.

[7] Ruky, Achmad S. 2002. Manajemen Penggajian dan Pengupahan Untuk Karyawan Perusahaan. Jakarta: PT. Gramedia Pustaka Utama

[8] Sugiyono. 2012. Metode Penelitian Administrasi. Bandung: Alfabeta

[9] Indriantoro, Nur. 2002. Penelitian Bisnis Untuk Akuntansi dan Manajemen.Edisi 2. Yogyakarta: BPFE.

[10] Nasir, M. 2003. Metode Penelitian. Jakarta: Ghalia Indonesia.

[11] Mulyadi. 2002. AuditingBuku Dua Edisi Keenam. Jakarta: Salemba Empat. 